\title{
PERANCANGAN APLIKASI DISPLAY AGENDA MEETING MENGGUNAKAN PHP DI PT. KINENTA INDONESIA PURWAKARTA
}

\author{
Ahmad Sahi S.Kom, M.Kom. \\ Dosen Program Studi Manajemen Informatika \\ Politeknik LP3I Bandung \\ e-mail : ahmadsahi.lp3i@yahoo.com
}

\begin{abstract}
Abstrak : Internet menjadi komponen penunjang untuk teknologi informasi. Internet mampu menghubungkan koneksi dari berbagai penjuru dunia dengan mudah. Dari perkembangan Internet inilah muncul aplikasi berbasis web. Aplikasi berbasis web adalah sebuah aplikasi yang dapat diakses melalui Internet. Kemudahan tersebut sudah banyak digunakan dalam kegiatan manajemen dalam suatu perusahaan. Kegiatan di perusahaan tidak lepas dari teknologi untuk penyimpanan dan pendistribusian data-data dalam skala besar dan tidak mungkin dilakukan secara manual karena akan menyita waktu yang lama dalam pengerjaannya.
\end{abstract}

Kata Kunci : Internet, Perancangan aplikasi display, sistem informasi

\section{Pendahuluan}

Menurut Information Technology Association of America (ITAA), teknologi informasi adalah suatu study, perancangan, pengembangan, implementasi dukungan atau manajemen sistem informasi berbasis komputer, khususnya aplikasi perangkat lunak dan perangkat keras komputer. TI memanfaatkan komputer elektronik dan perangkat lunak komputer untuk mengubah, menyimpan, melindungi, memproses, mentransmisikan dan memperoleh informasi secara aman.

Teknologi informasi dewasa ini menjadi hal yang sangat penting karena sudah banyak organisasi yang menerapkan teknologi informasi untuk mendukung kegiatan organisasi. Teknologi informasi diterapkan untuk pengolahan informasi yang menjadi salah satu bagian penting karena meningkatnya kompleksitas dari tugas manajemen maupun pengaruh ekonomi internasional. Sistem informasi ini mengumpulkan, memproses, menyimpan, menganalisis, menyebarkan informasi untuk tujuan tertentu.

Kecanggihan teknologi kini telah masuk ke instansi-instansi maupun perushaan untuk di manfaatkan menjadi penunjang pekerjaan karena menjadi lebih efisien. Bahkan kecangihan teknologi mampu memudahkan kita melakukan pekerjaan di manapun kita berada. Teknologi tidak lepas dari peran Internet sebagai penghubung, karena Internet mampu mengakses secara global dengan cara yang sangat cepat.

\section{Rumusan Masalah}

PT. KINENTA Indonesia adalah perusahaan yang bergerak di bidang wiring harness yang berada di kota Purwakarta. Masalah yang sekarang di hadapi adalah ketidak pastiaan agenda Meeting di PT. KINENTA yang sering kali terjadi, seperti penuhnya ruangan utama Meeting, bentrok nya jadwal agenda Meeting disetiap departement dikarenakan tidak adanya informasi yang mengatur agenda Meeting setiap departement yang ada di PT. KINENTA indonesia. Seperti yang kita ketahui Meeting atau rapat merupakan kebutuhan di setiap instansi atau pun perusahaan untuk mencapi keputusan bersama, juga pemecahan masalah yang sedang terjadi. Setiap departemen yang mengikuti kegiatan rapat terbagi menjadi dua yaitu Meeting yang bersifat rutin dan Meeting kontemporer atau sewaktu-waktu. Dapat disimpulkan jika tidak ada System yang mengatur agenda 
tersebut dapat mengakibatkan ketidak efisiensi nya waktu kerja, pemunduran agenda bahkan bisa saja gagal untuk pelaksaan Meeting. Oleh sebab itu, diperlukan System untuk mengatur agenda maupun menentukan agenda agar tidak terjadi deviasi agenda lagi, jadi Setiap departement yang akan melakukan Meeting diharuskan mebuat agenda di dalam System, yang kemudian akan di olah manjadi sebuah display agenda Meeting yang mampu di akses di aplikasi berbasis web. Untuk membuat aplikasi tersebut penulis menggunakan bahasa PHP (Hypertext Preprocessor) yang mendukung untuk pembualatan aplikasi berbasis web.

\section{System yang Berjalan}

System yang berjalan digambarkan dalam Activity Diagram, yaitu :

Prosedur Pembuatan Agenda

Proses Activity Diagram dibawah ini adalah proses dari Prosedur Pembuatan Agenda. Dimana proses tersebut dimulai dari Departement Head selaku pimpinan dari departemen yang meminta untuk menjadwalkan Meeting di hari dan waktu yang di perlukan untuk segera di laksnakan dan mengundang pimpinan dari departement lain nya sesuai kebutuhan kepada pihak PIC yang merupakan bagian manajemen administrasi. Selanjutnya PIC menjadwalkan Agenda Meeting yang di perlukan oleh pimpinannya. Setelah itu PIC memproses agenda dan mengirim pesan via email, Skype dan juga BBM ke pada setiap PIC departement lain yang di undang. PIC yang mengundang harus menunggu konfirmasi dari Attendance sebagai konfirmasi bahwa

a. Agenda Meeting sepakat akan di laksanakan sesuai yang di agendakan. Kemudian PIC membuat laporan kepada departement Head agenda Meeting akan atau tidak akan dilakasaakan agenda Meeting. 


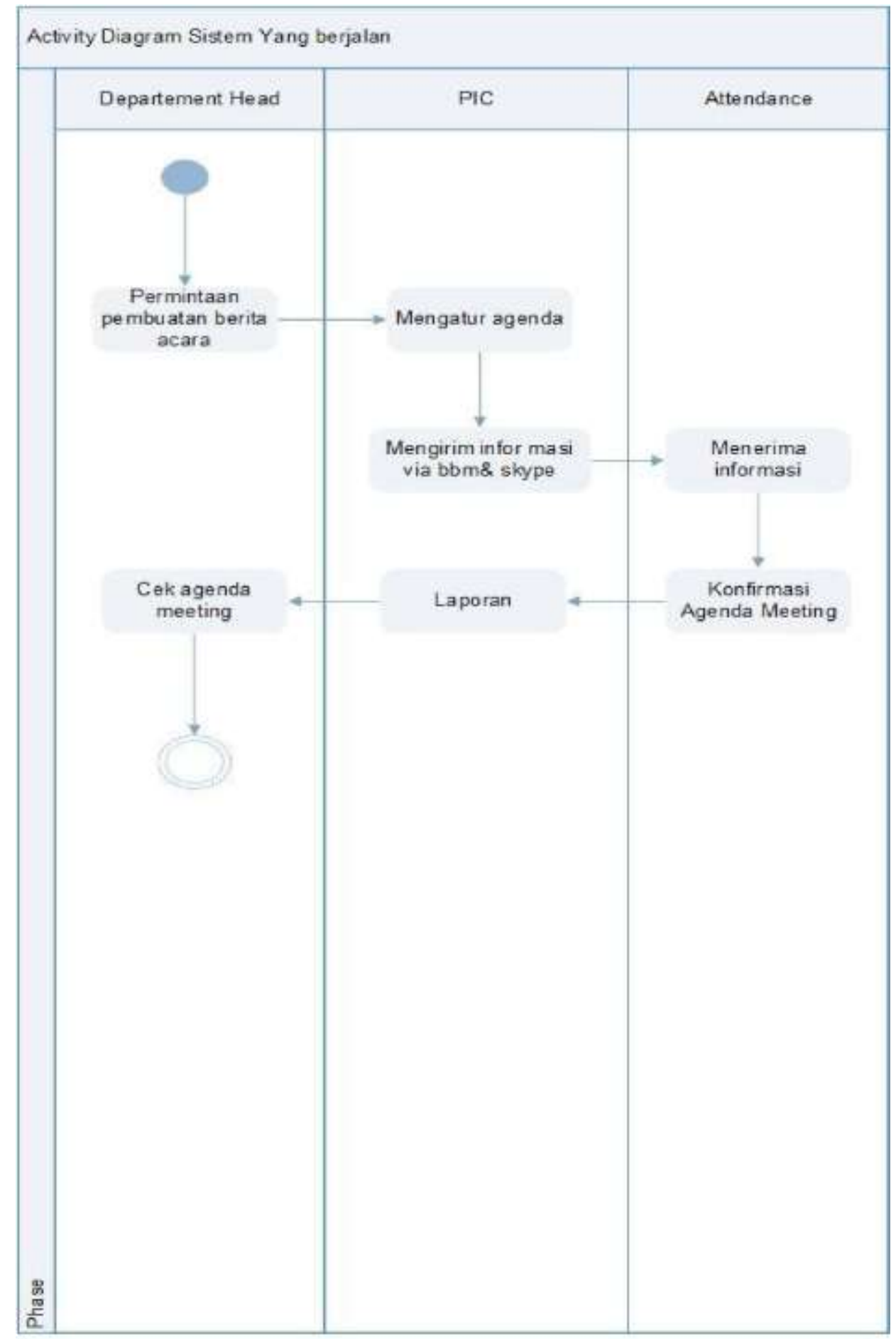

Gambar 1. Prosedur Pembuatan agenda Sumber: PIC Departement IT 


\section{Pembahasan}

Untuk user sebagai admin, ada beberapa tahapan yang harus dipahami sebagai admin. Admin Database

Berhubung database yang akan di gunakan adalah mysql maka ada beberapa aplikasi pendukung yang harus di aktifkan seperti xampp yang merupakan aplikasi server. Berikut adalah cara pengaktifan xampp:

\section{Aktifkan Xampp Control Panel}

membuat database di mysql.

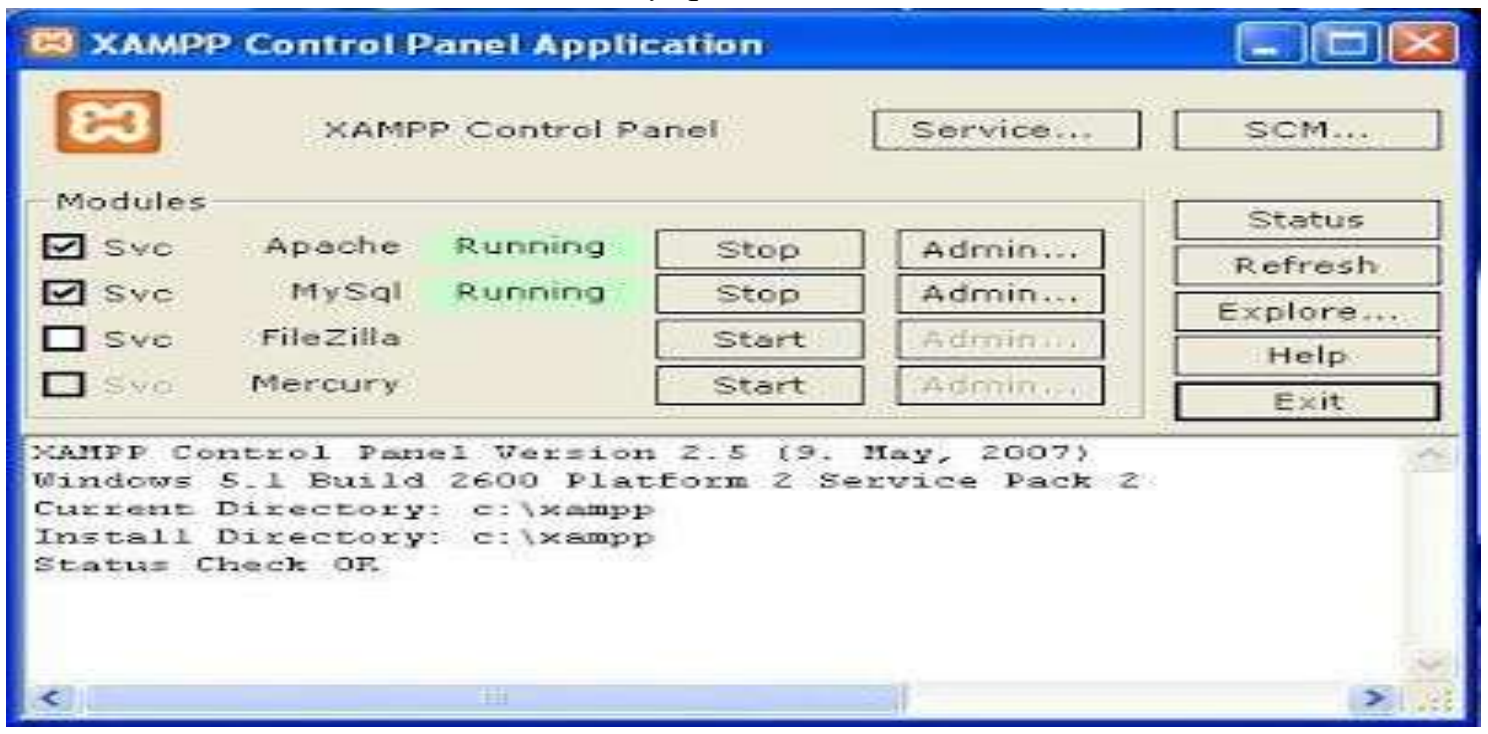

Gambar 2. Control Panel

Mysql dan Apache terlebih dahulu harus di aktifkan sebelum

2. Login ke database Mysql

3. Gunakan Browser Mozila kemudian masuk ke localhost Di tahap admin database ini ada beberapa cara yang bisa dilakukan.

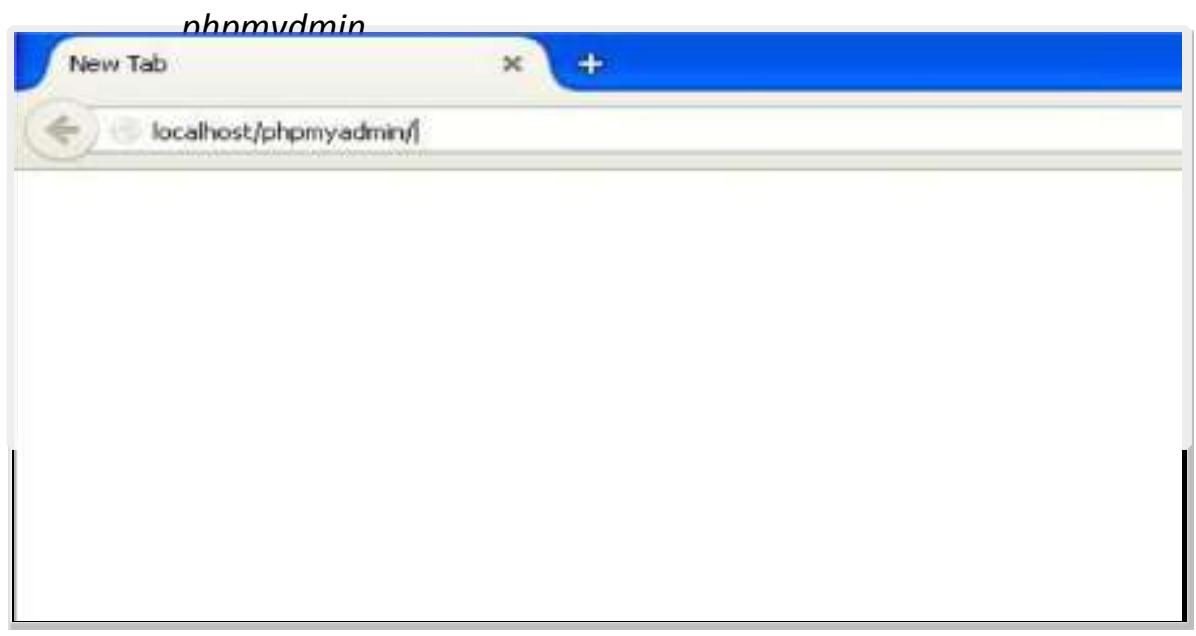

Browser

Berikut ini penjelasannya : 
a. Buat database baru

Diantaranya :

1) Buat database baru

2) Import Database

3) Ubah User Password

4) Ekspor Database

5) Hapus Database

Cara membuat database :

Pembuatan database baru untuk aplikasi agenda meeting.

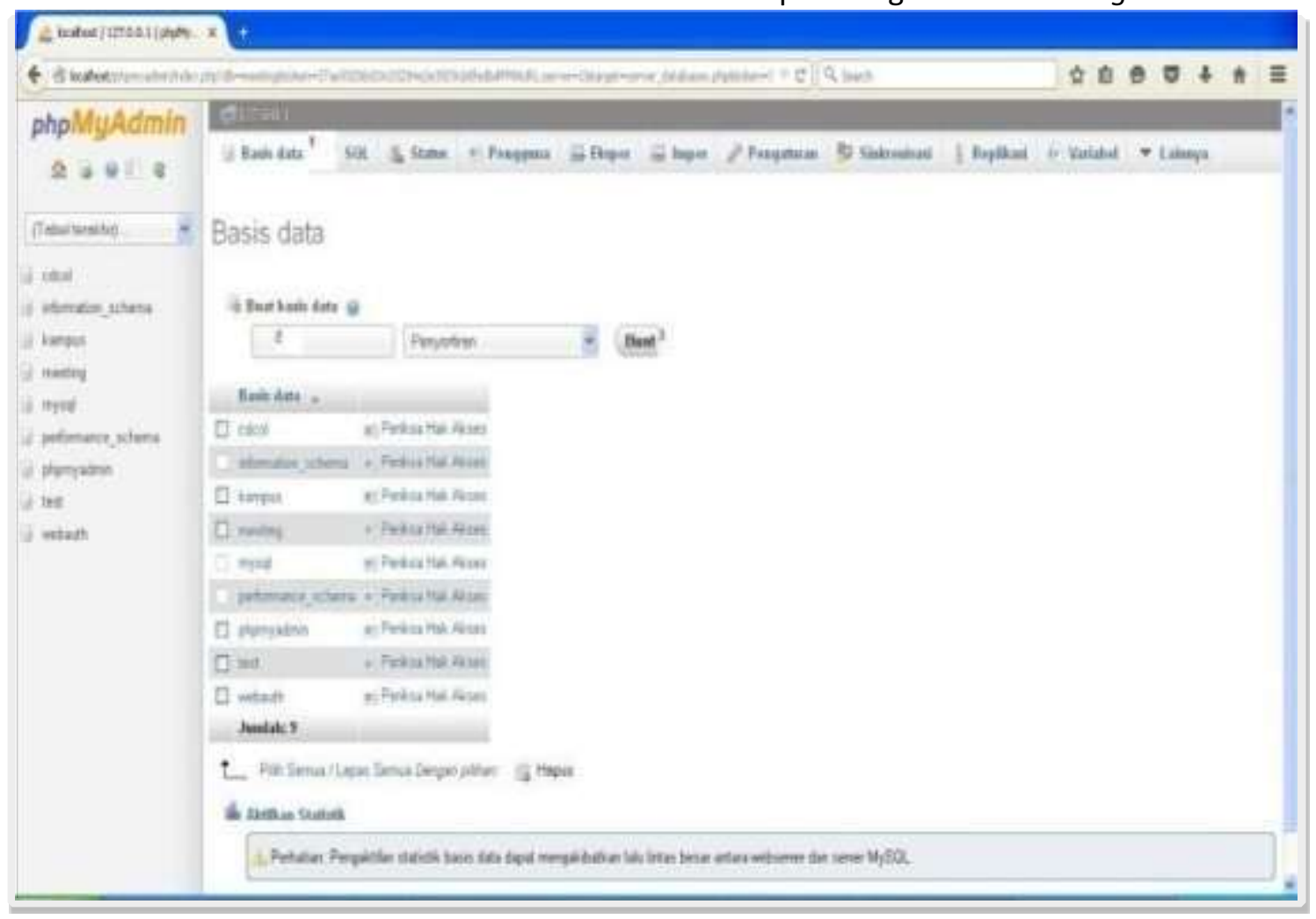

Buat Database

1) Untuk membuat Database baru

2) Sesuaikan nama database

3) Untuk mengeksekusi database baru

b. Import Database 


\section{Cara Import Database :}

Mengambil data dari database yang sudah di buat.

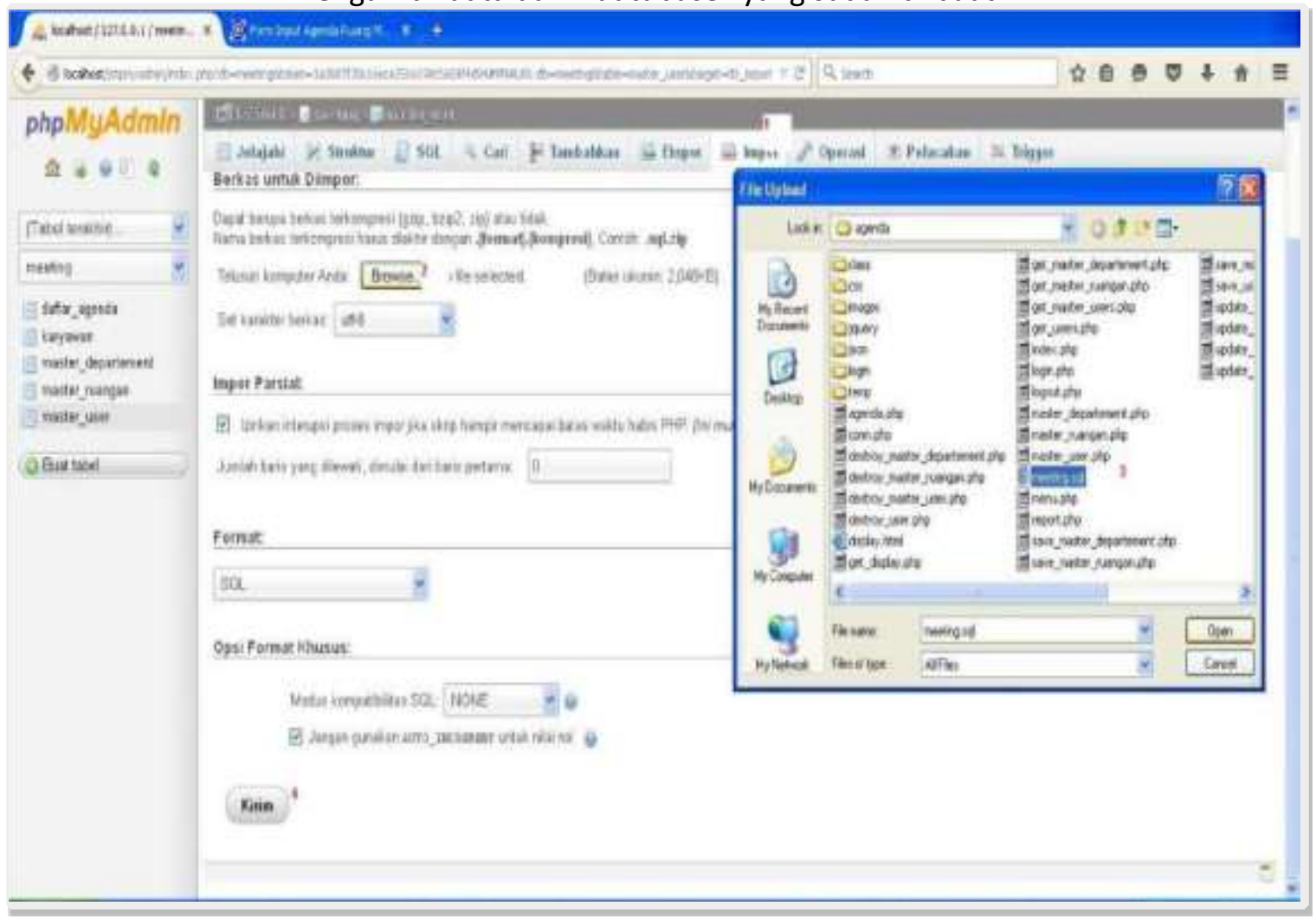

\section{Buat Database}

1) Untuk masuk kehalaman import database

2) Mencari File di drive computer

3) Memilih File yang akan di import

c. Ubah User Password

User Password merupakan akses untuk Login di aplikasi meeting. 


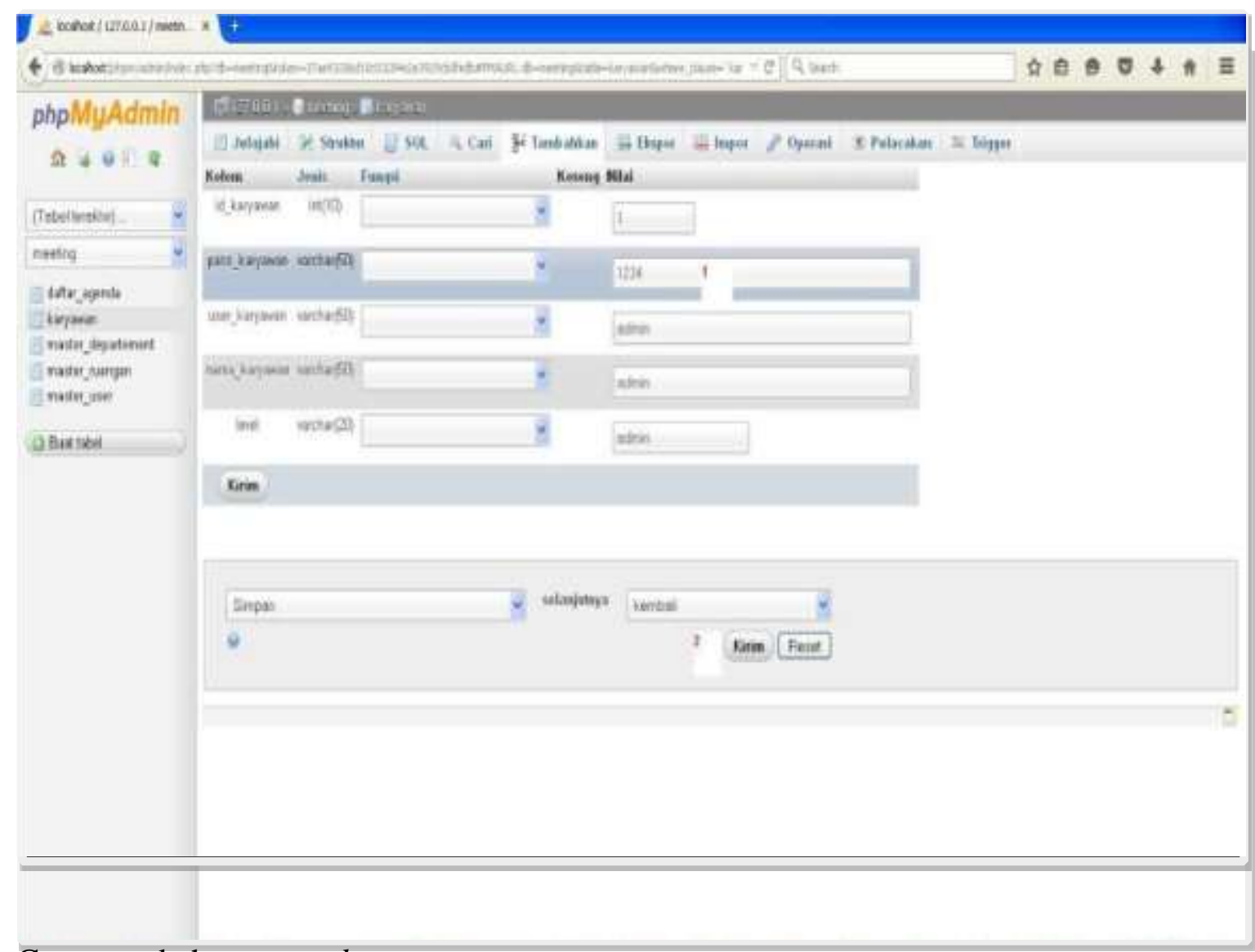

Cara merubah password:

1) Tentukan table yang akan di ubah ,lalu ubah field password karyawan.

2) Kemudian save atau kirim.

\section{d. Eksport Database}

Cara Untuk mengeksport database:

1) Masuk kehalaman eksport

2) Untuk mengambil data

e. Hapus database

Cara untuk menghapus database: 


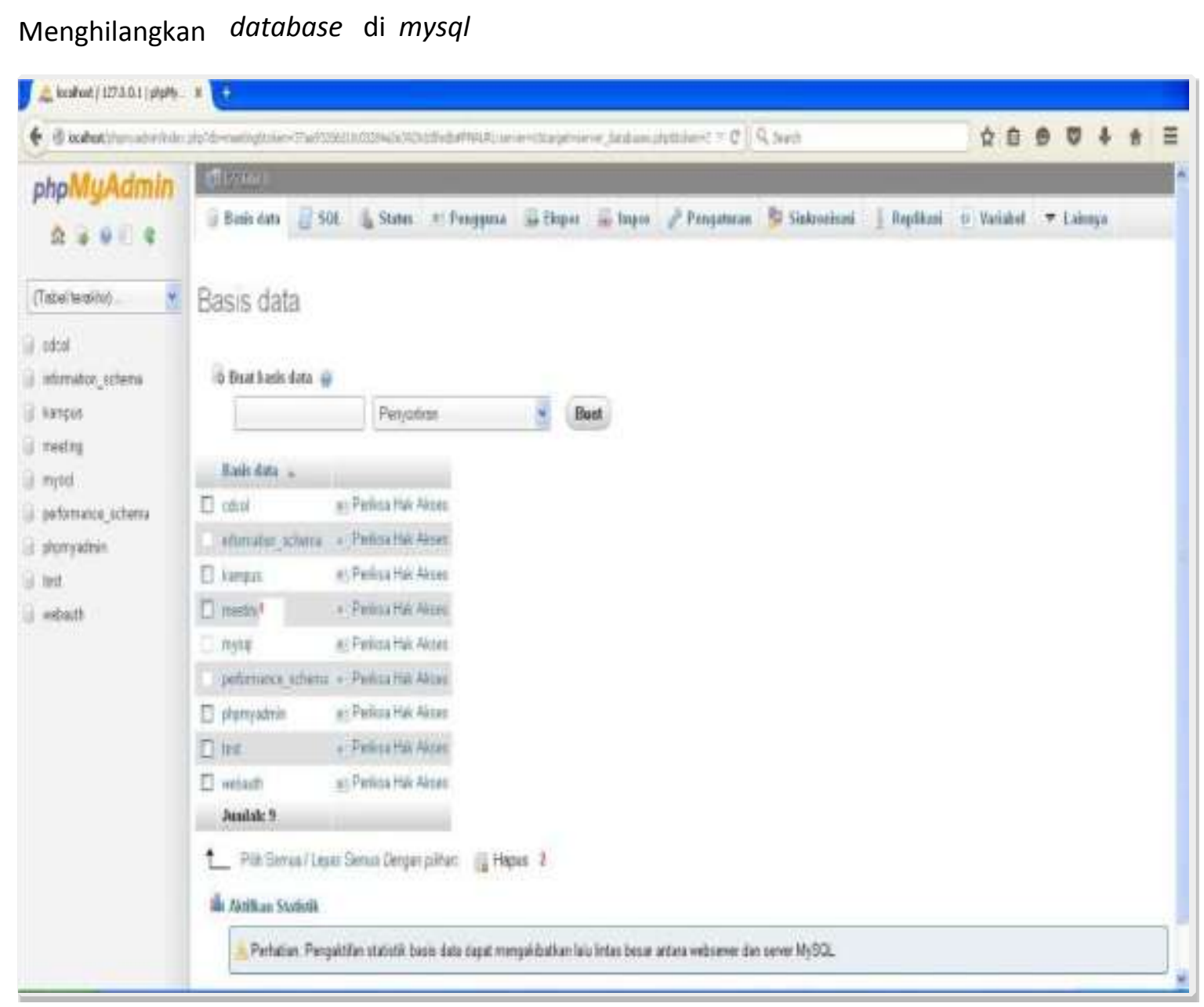

Eksport Database

1) Pilih database yang akan di hapus lalu ceklis

2) Untuk mengeksekusi

\section{Admin PIC}

PIC merupakan admin di aplikasi agenda meeting, yang mempunyai wewenang untuk mengaplikasikan agenda meeting.Setiap departement memiliki satu orang bahkan ada yang memiliki 3 orang sekaligus sesuai kebutuhan departement.

Seorang admin atau juga PIC(Person In Charge) akan mengInput kebutuhan agenda meeting yang di minta oleh Departement Head mulai dari menentukan agenda, ruangan dan attendace. Kemudian PIC mengkonfirmasi kepada PIC Attendance mengenai agenda yang telah di ajukan oleh pihak departement tuntuk membahas sesuatu perihal.

Di tahap PIC admin ada beberapa tahap yang bisa di lakukan Diantaranya adalah :

1) Login Sebagai admin

2) Form Menu

3) Input master Ruangan

4) Input master Departement

5) Input master User/PIC 
6) Input agenda Meeting

7) Display yang berjalan Berikut Penjelasannya :

\subsection{Login Sebagai admin}

Untuk menjalankan aplikasi agenda, jalankan Mozilla Fire Fox,Internet Explorer, atau Browser lainnya. Kemudian ketik alamat server aplikasi ditempatkan 192.168.4.222/agenda, Sehingga muncul screen login seperti dibawah ini :
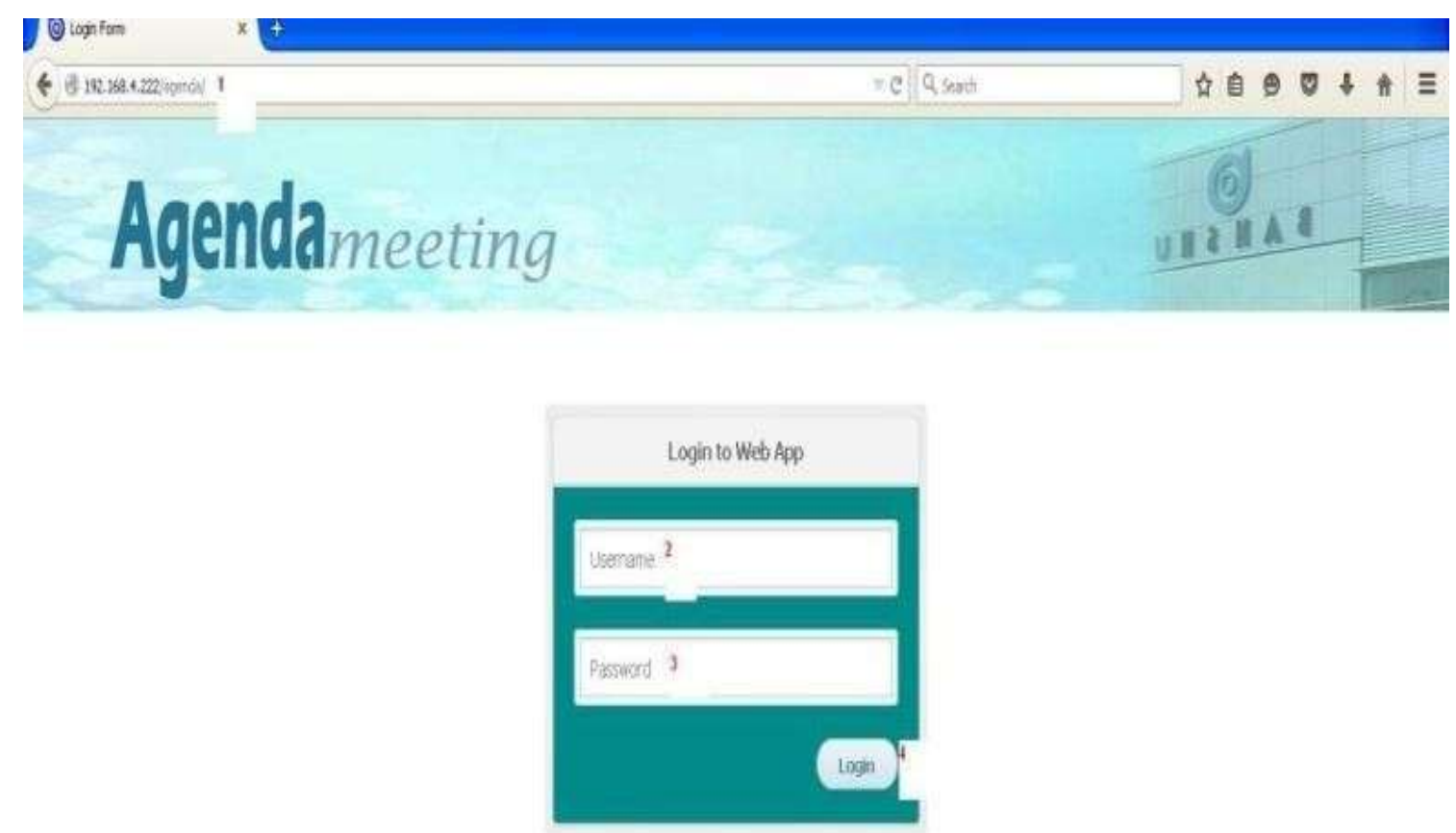

Cara untuk Login ke aplikasi agenda meeting: 
Ketik alamat server apilakasi

Mengisi User name sesuai kebutuhan

1) Mengsi Password yang sesuai dengan User name

2) Eksekusi untukke Form selanjutnya

\subsection{Form Menu}

form menu merupakan daftar master, display agenda meeting Cara menggunakan Form Menu :

1) Logout untuk mengakhiri login aplikasi

2) Sub Master yang terdiri dari beberapa master

3) Sub Display agenda

\subsection{Input Master Ruangan}

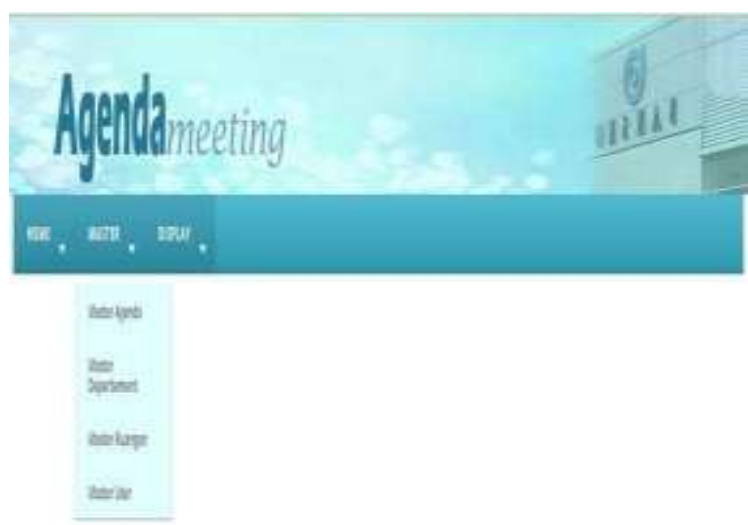

Cara menggunakan Form Ruangan dan pengenalan Tools yang ada di Grid aplikasi :

a. Untuk inputan data baru

b. Jika tombol New data di tekan akan muncul list baru di bagian bawah grid untuk di input data baru.

c. Jika data yang di input sudah sesuai dengan kebutuhan lalu klit tombol save

d. Merupakan icon untuk reload grid jika terdapat inputan yang belum muncul di grid. Fungsinya sama seperti perintah refresh.

e. Merupakan icon Next last page dari data grid

f. Merupakan icon Next page

g. Merupakan Setingan Sortir data di grid

h. Untuk edit data bisa langsung di klik dari list gridnya kemudian klik save.

i. Icon cancel digunakan untuk membatalkan perintah Input Juga saat melakukan edit data

\subsection{Input Master Departement}

Merupakan Inputan master Departement sesuai data dari PT. KINENTA Cara Penggunaan Master Departement : 

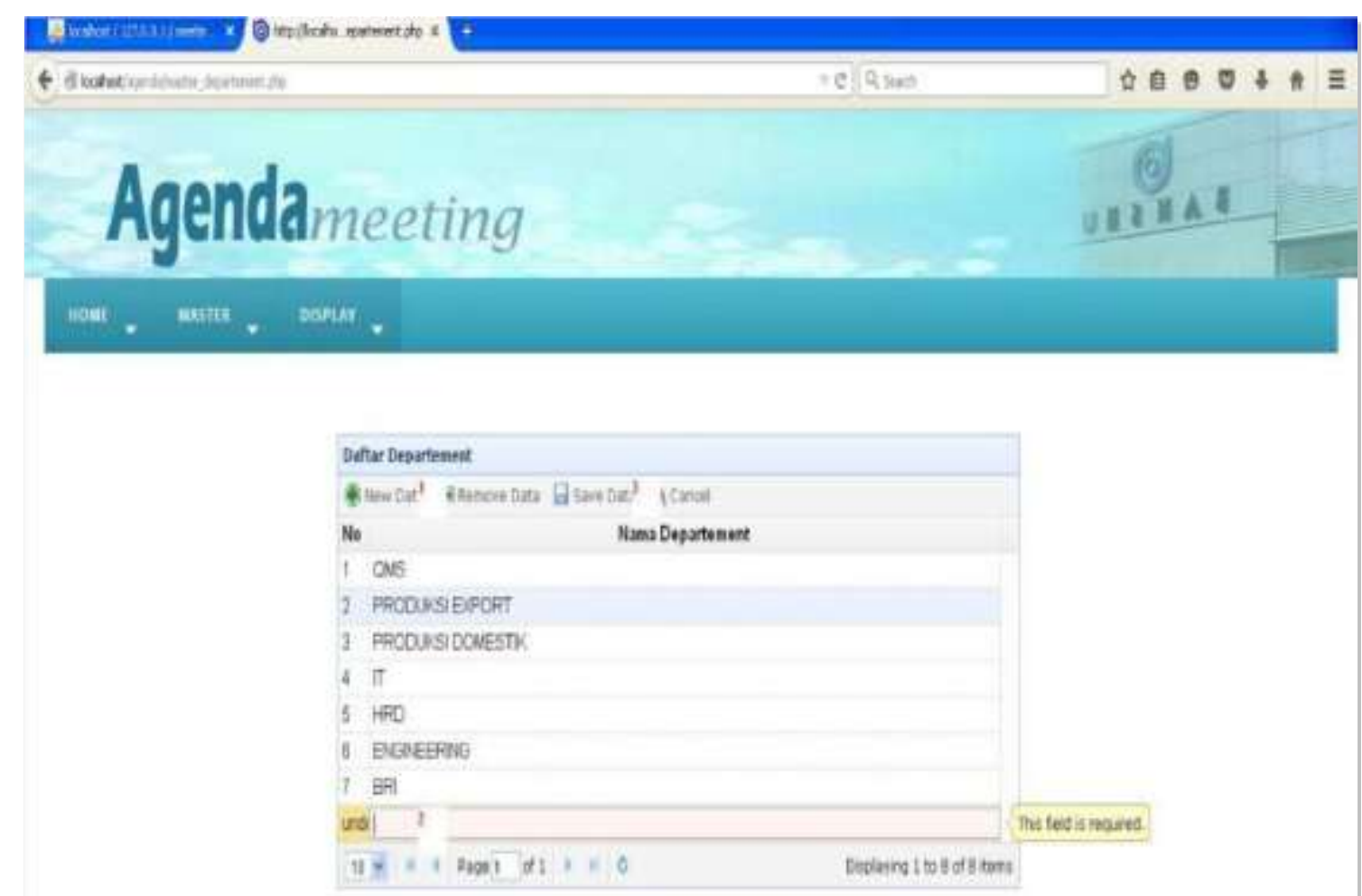

Form Master Departemen

1) Untuk inputan data baru

2) Jika tombol Newdata di tekan akan muncul list baru di bagian bawah grid untuk di input data baru.

3) Jika data yang di input sudah sesuai dengan kebutuhan lalu klik tombol save.

\subsection{Input Master User}

PIC PIC atau juga admin merupakan user yang akan akan membuat agenda meeting sesuai kebutuhan department head Cara menggunakan Master User/PIC :

1) Isi kan data diri User PIC berikut dengan departement

2) Merupakan Combobox yang berisi daftar Departement yang di ambil dari master Departement.

3) Jika data sudah sesuai Klit tombol save untuk Menyimpan di system.

\subsection{Input Agenda Meeting}

Proses yang merupakan dari inti aplikasi agenda meeting. Dari form agenda Ini lah agenda meeting akan membuat agenda sesuai data yang di butuhkan mulai dari keperluan ruangan,waktu,dan attendance.

Cara menggunakan Form Input Agenda Meeting :

1) Input data baru

2) Isikan data sesui Kebutuhan. System akan otomatis membuat validasi jiga data ada kesamaan atau agenda di ruangan meeting sedang di gunakan, maka PIC admin harus mencari waktu atau ruangan lain.

3) Simpan data jika sudah sesuai. 


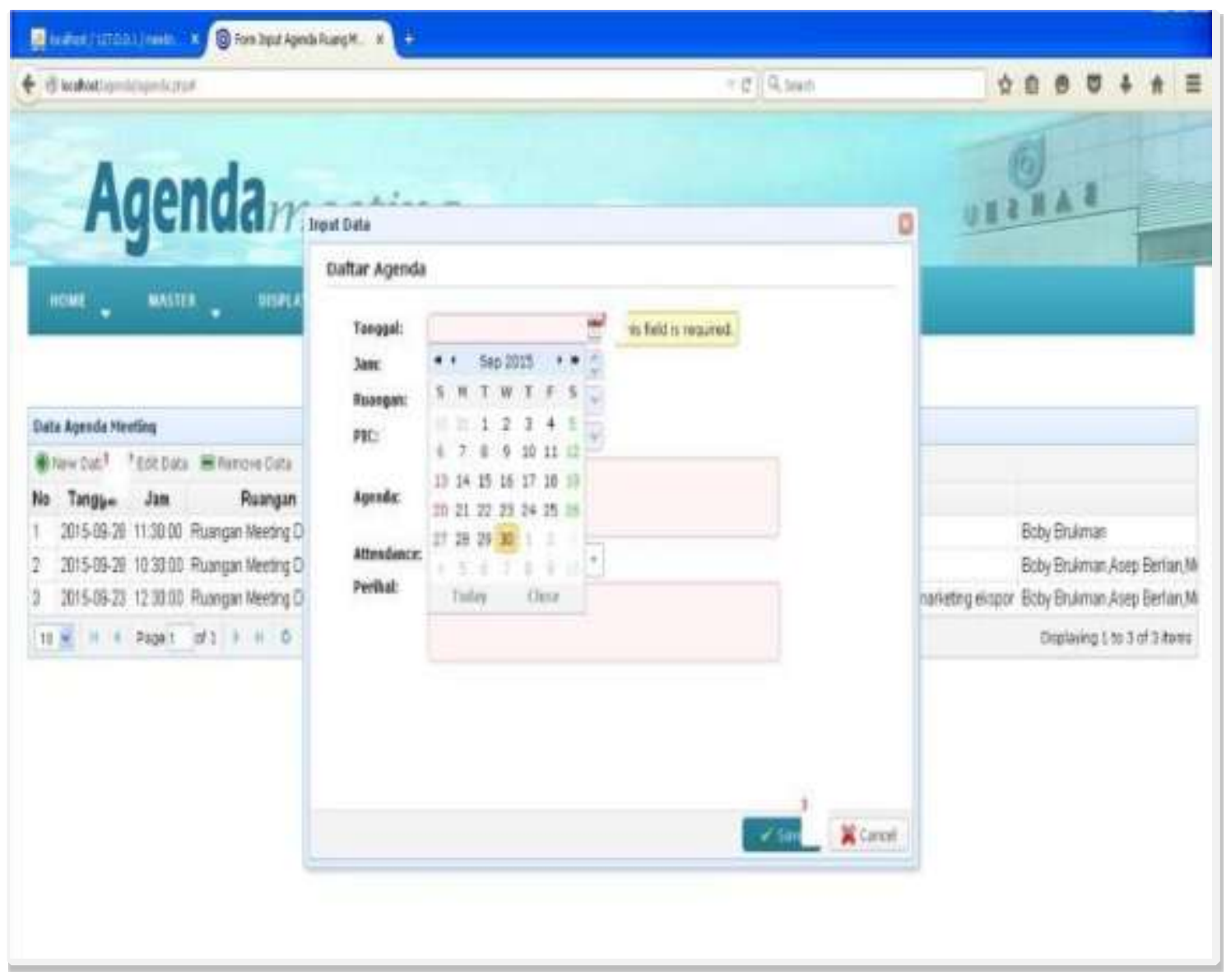

Input Agenda Meeting

\subsection{Display yang berjalan}

○ Agenda Ruang Meeting

\begin{tabular}{|c|c|c|c|c|c|}
\hline Tanggal & Jam & Ruangan & PIC & Departement & Ageeda \\
\hline $15 \cdot 00=0$ & de 30.00 & Ruarpen Moeting Domest' & Mehamad Fater Awaludin Shaleh & Fecourst Expet & Mooting al has tans \\
\hline
\end{tabular}

2015-00-30 09:30t00 Pusangan Meeting Dones' Muhamad Fajar Awaludin Shaich PRODUKSI EXPORT Meethe Kordirasi finishinj software ltpF

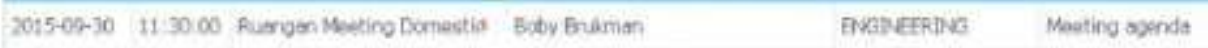


Merupakan Tanmpilan dari data master agenda yang akan berjalan.

Implementasi Display agenda :

1) Daftar list yang sudah Melewati waktu agenda meeting akan berada di atas dari garis warna biru.

2) Daftar list yang blum dimulai agenda meeting berada di bawah garis biru.

3) Garis biru menandakan agenda yang sedang berlangsung.

\section{8 User Manual Admin}

Untuk user sebagai User biasa, hanya ada 2 tahap karena aplikasi ini memudahkan user untuk mengingat agenda saja. Berikut adalah tahapan yang harus di lalui user :

\section{a. User Login}

Untuk menjalankan aplikasi agenda ,jalankan Mozilla Fire Fox,Internet Explorer atau Browser lainnya. Kemudian ketik alamat server aplikasi itempatkan 192.168.4.222/agenda, sehingga muncul screen Login
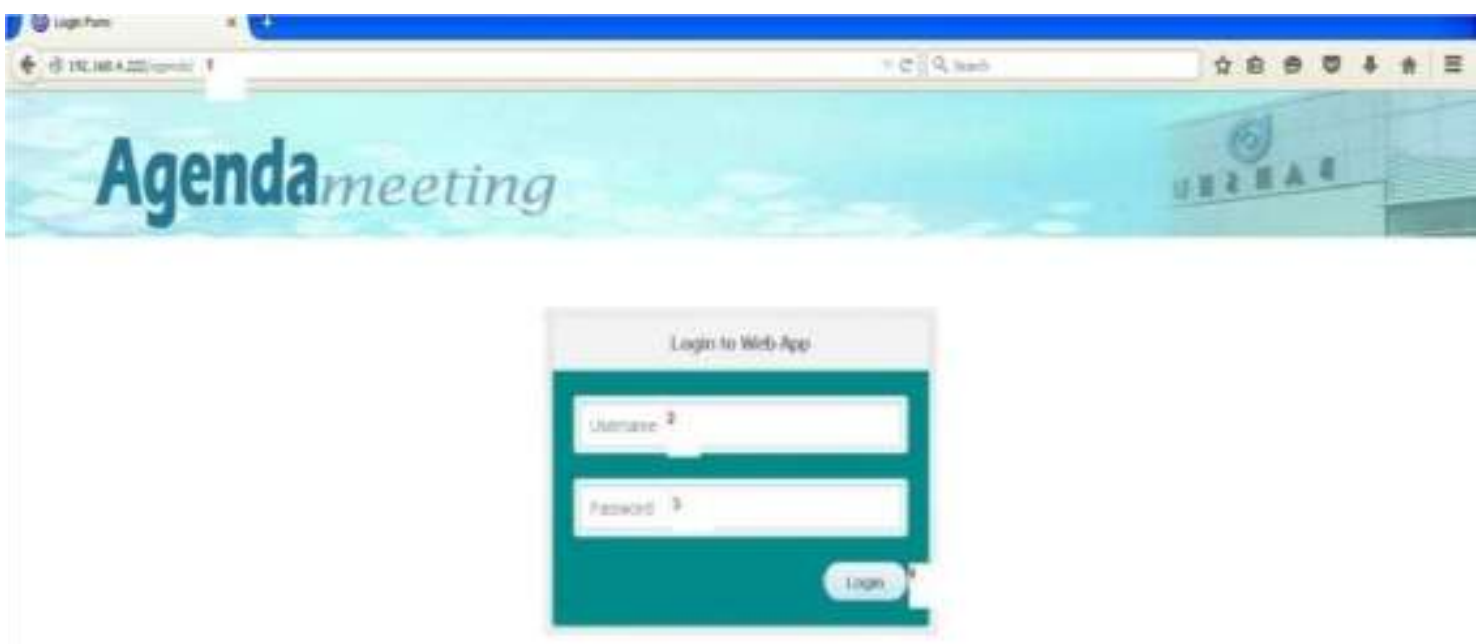

\section{Form Login}

Cara untuk Login ke aplikasi agenda meeting:

1) Ketikan alamat server apilakasi

2) Mengisi User name sesuai kebutuhan

3) Mengsi Password yang sesuai dengan Username

4) Eksekusi untuk ke Form selanjutnya langsung ke display Agenda Meeting.

\section{Display Agenda Meeting}


Login sebagai User hanya bisa melihat display saja

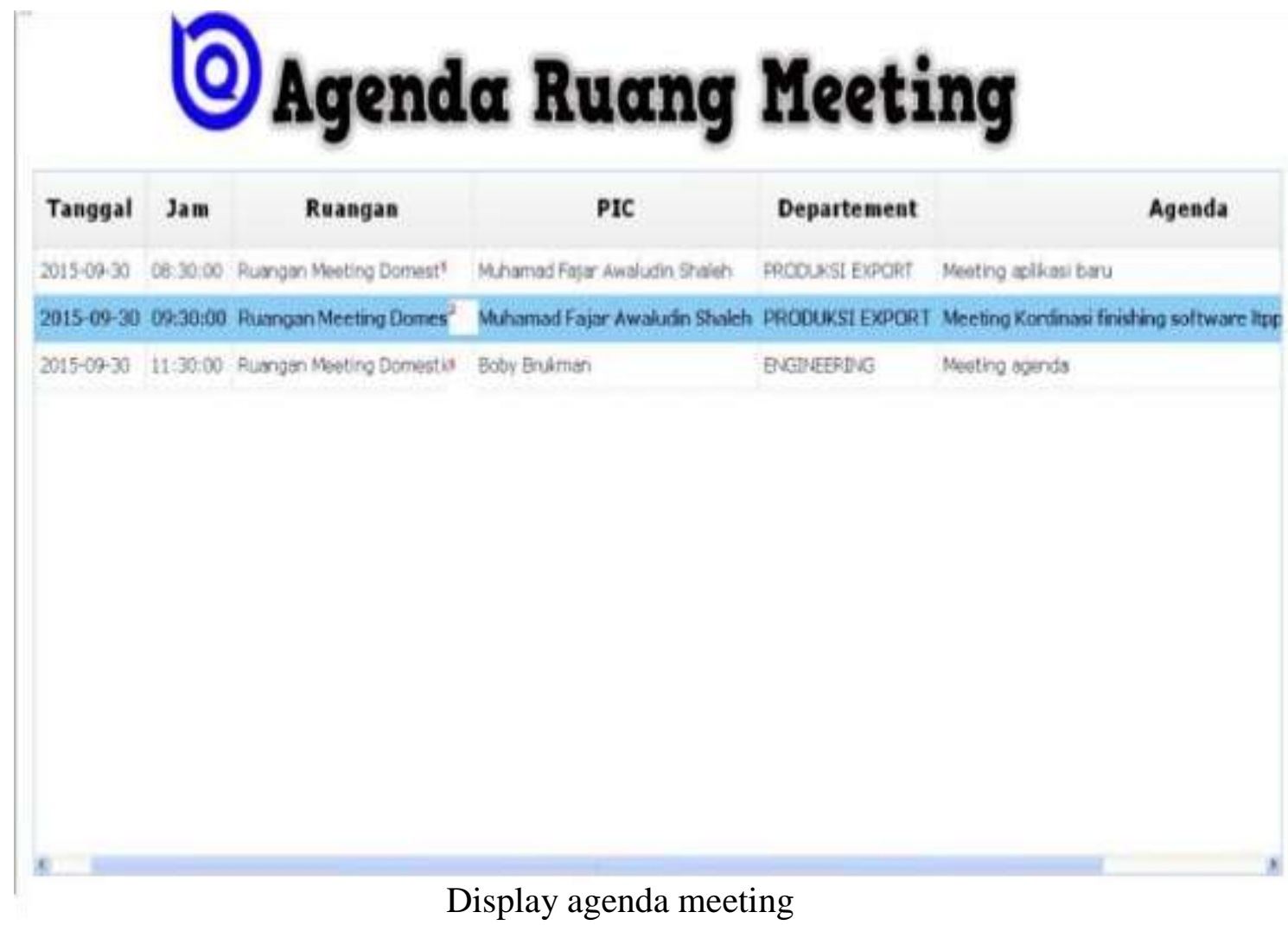

Display agenda meeting

Merupakan Tampilan dari data master agenda yang akan berjalan.

Implementasi Display agenda :

1) Daftar list yang sudah Melewati waktu agenda meeting akan berada di atas dari garis warna biru.

2) Daftar list yang blum dimulai agenda meeting berada di bawah garis biru.

\section{Daftar Pustaka}

[1] Jquery Easyui framework 2010

[2] Martin Fowler.Uml Distilled Edisi 3, Panduan Singkat Bahasa Pemodelan Objek Standar, Penerbit andi

[3] Aminudin, penerbit Ankasa, tahun terbit 2014 Ensiklopedia, Teknologi informasi

[4] Evi Triandini \& Gede Suardika, Step By Step Desain Proyek Menggunakan UML, CV. Andi Offset, Yogyakarta, 2012 